\title{
Reliable and Sensitive Detection of Acidovorax citrulli in Cucurbit Seed Using a Padlock-Probe-Based Assay
}

Yanli Tian, College of Plant Protection and Key Laboratory of Integrated Management of Crop Diseases and Pests, Ministry of Education, Nanjing Agricultural University, Nanjing 210095, China; Yuqiang Zhao, Shanghai Agricultural Technology Extension and Service Center; Shanghai 201103, China; Sa Bai, College of Plant Protection and Key Laboratory of Integrated Management of Crop Diseases and Pests, Ministry of Education, Nanjing Agricultural University; R. R. Walcott, Department of Plant Pathology, University of Georgia, Athens 30602; Baishi Hu, College of Plant Protection and Key Laboratory of Integrated Management of Crop Diseases and Pests, Ministry of Education, Nanjing Agricultural University, and National Engineering Research Center For Cucurbits, Changji 831100,China; and Fengquan Liu, College of Plant Protection and Key Laboratory of Integrated Management of Crop Diseases and Pests, Ministry of Education, Nanjing Agricultural University

\begin{abstract}
Tian, Y., Zhao, Y., Bai, S., Walcott, R. R., Hu, B., and Liu, F. 2013. Reliable and sensitive detection of Acidovorax citrulli in cucurbit seed using a padlock-probe-based assay. Plant Dis. 97:961-966.

A method was developed using a padlock probe (PLP) and dot-blot hybridization for detecting Acidovorax citrulli in cucurbit seed. The PLP was designed based on the 16S-23S internal transcribed spacer ribosomal DNA sequence from A. citrulli. The detection threshold for the PLP assay was $100 \mathrm{fg}$ of genomic DNA, and A. citrulli was detected in $100 \%$ of artificially infested seedlots with $0.1 \%$ infestation or greater. In addition, using the PLP assay, 4 of 8 melon seedlots

collected from Xinjang province and 15 of 47 watermelon seedlots collected from Ningxia province were positive for A. citrulli. In contrast, a conventional polymerase chain reaction (PCR) assay that relied on primers WFB1 and WFB2 facilitated A. citrulli detection in 1 of 8 and 5 of 47 seedlots from Xinjiang and Ningxia provinces, respectively. These data indicate that the PLP and dot-blot hybridization technique was more effective than conventional PCR for seed health testing.
\end{abstract}

Bacterial fruit blotch (BFB), caused by Acidovorax citrulli (formerly A. avenae subsp. citrulli) (19,31), is a devastating seedborne disease of many cucurbitaceous species. Since the first observation in commercial production fields in 1965 (29), BFB has caused millions of dollars of losses in many cucurbit-producing regions of the world (5). Perennially, China produces the greatest number of watermelon and melon crops in the world. However, in recent years, watermelon and melon crops in many provinces have been affected by BFB, including Xinjiang (23), Jilin (10), Neimenggu (9), Gansu (32), Shandong (34), Fujian (6), and Guangdong (17). The disease has caused significant economic losses for both fruit and seed producers.

Infested seedlots are the most important source of primary inoculum for BFB outbreaks (16). Hence, effective BFB management requires that all commercial watermelon and melon seed be tested for freedom from A. citrulli. Routinely, cucurbit seed are tested for $A$. citrulli by the seedling grow-out assay or by isolating the pathogen from the seed on semiselective media. However, these assays are generally considered time consuming and inefficient. Recently, polymerase chain reaction (PCR)-based assays were developed for the detection of A. citrulli $(14,27)$. Unfortunately, many seeds contain compounds that inhibit PCR and can lead to false-negative results in seed heath tests $(4,27)$.

Recently, a diagnostic method was developed based on padlock probes (PLPs) to improve detection sensitivity and reduce the cost and time required for diagnosis (15). PLPs are long oligonucleo-

Corresponding author: B. Hu, E-mail: hbs@njau.edu.cn

The first two authors contributed equally to this research.

* The $\boldsymbol{e}$-Xtra logo stands for "electronic extra" and indicates that a supplementary figure is available online and that Figure 1 appears in color online.

Accepted for publication 24 January 2013.

http://dx.doi.org/10.1094/PDIS-10-12-0930-RE

(C) 2013 The American Phytopathological Society tides (approximately $100 \mathrm{bp}$ ), whose ends are complementary to sequences adjacent to the site targeted for PCR amplification (Supplementary Figure 1). Upon hybridization to the target, the $5^{\prime}$ and $3^{\prime}$ ends of the PLPs are brought into contact, allowing circularization by ligation. This ligation and resulting circularization can only take place when both flanks hybridize to their target sequences correctly. Noncircularized probes are removed by exonuclease activity. PLPs provide extremely specific target sequence recognition, which is followed by universal amplification and detection by microarray analysis (22). PLPs, combined with universal PCR amplification and microarray detection, have facilitated the simultaneous detection of several important plant pathogens, and all pathogens can be detected using this approach. For example, this approach has been used to detect human-pathogenic viruses $(21,28)$, bacteria (23), and fungi (11) and plant-pathogenic fungi (24). To date, the technique has not been reported for the detection of plant-pathogenic bacteria.

We developed an assay that combines PLP with dot-blot hybridization to detect $A$. citrulli in seed extracts. To detect the bacterium on different samples on a single nylon membrane, the target-specific products were detected by dot-blot hybridization. Briefly, circularized probes were amplified using nonlabeled universal primers, PLP amplicons were spotted onto the nylon membrane, and the cZipCode oligonucleotides were digoxigenin labeled, hybridized to the PLP amplicons, and visualized with a chromogenic assay. In this study, we report the use of the PLP in combination with dot-blot hybridization for reliable and sensitive detection of $A$. citrulli in cucurbit seed.

\section{Materials and Methods}

Bacterial strains and DNA extraction. In total, 112 bacteria strains, including 75 strains of $A$. citrulli and 37 related species, were obtained (Table 1). Genomic DNA was extracted from all strains strain using a TIANamp Bacteria DNA Kit (TIANamp BIOTECH )according to the manufacturer's directions.

PLP design. The PLP designed for A. citrulli was $102 \mathrm{bp}$ and contained regions complementary to the A. citrulli target region flank at the $5^{\prime}$ and $3^{\prime}$ ends. Between these segments lie the univer- 
sal primer sites and a unique sequence identifier, called Zipcode. The PLP was designed as described previously (22). The asymmetric $5^{\prime}$ arm of the PLP was longer than its $3^{\prime}$ arm. The PLP was designed to target unique A. citrulli $16 \mathrm{~S}-23 \mathrm{~S}$ internal transcribed spacer (ITS) ribosomal (r)DNA sequences. Sequences available in GenBank and those obtained from independent sequencing studies were aligned, and sequences unique to $A$. citrulli were selected (Fig. 1). Based on the principles described previously, we designed a PLP, P-Ac (CCGGCGGCACGGTGCAGTTTCCTGCTTT CTCGACCGTTAGCAGCATGACCGAGATGTACCGCTATCGT
CCTTACGCTAGGTCGAGAGTTCAAATTTTGTCA) that was specific to $A$. citrulli. The $5^{\prime}$ and $3^{\prime}$ ends of the PLP P-Ac, T1 and $\mathrm{T} 2$, that are complementary to the target sequences, are indicated by dotted lines. The $5^{\prime}$ arm sequence (T1) is 28 nucleotides (nt) long and the $3^{\prime}$ arm sequence (T2) is $14 \mathrm{nt}$ long. The regions where the two PLP-specific primers $\left(\mathrm{P}_{1}-\mathrm{F}\right.$ and $\left.\mathrm{P}_{2}-\mathrm{R}\right)$ (22) bind for PCR amplification are underlined. The Zipcode sequence, with the unique sequence specific to the pathogen or target to be detected, is in bold. The unique identifier sequence was selected from an National Center for Biotechnology Information accession

Table 1. Bacterial strains used in this study

\begin{tabular}{|c|c|c|c|c|c|}
\hline No. & Strains & Host & Origin & Reference or source $^{\mathbf{a}}$ & $\mathbf{P L P}^{\mathbf{b}}$ \\
\hline & Acidovorax citrulli & & & & \\
\hline 1 & Njf01 & Cantaloupe & Xinjiang, China & Hu Baishi, Nanjing Agricultural University & + \\
\hline 2 & $\mathrm{Njf02}$ & Cantaloupe & Xinjiang, China & Hu Baishi, Nanjing Agricultural University & + \\
\hline 3 & $\mathrm{Nj101}$ & Cantaloupe & Xinjiang, China & Hu Baishi, Nanjing Agricultural University & + \\
\hline 4 & Xj104 & Cantaloupe & Xinjiang, China & Hu Baishi, Nanjing Agricultural University & + \\
\hline 5 & Xj112 & Cantaloupe & Xinjiang, China & Hu Baishi, Nanjing Agricultural University & + \\
\hline 6 & $\mathrm{Xj} 120$ & Cantaloupe & Xinjiang, China & Hu Baishi, Nanjing Agricultural University & + \\
\hline 7 & Bt101 & Cantaloupe & Xinjiang, China & Hu Baishi, Nanjing Agricultural University & + \\
\hline 8 & Bt102 & Cantaloupe & Xinjiang, China & Hu Baishi, Nanjing Agricultural University & + \\
\hline 9 & Bt103 & Cantaloupe & Xinjiang, China & Hu Baishi, Nanjing Agricultural University & + \\
\hline 10 & Cj101 & Cantaloupe & Xinjiang, China & Hu Baishi, Nanjing Agricultural University & + \\
\hline 11 & Cj102 & Cantaloupe & Xinjiang, China & Hu Baishi, Nanjing Agricultural University & + \\
\hline 12 & Cj103 & Cantaloupe & Xinjiang, China & Hu Baishi, Nanjing Agricultural University & + \\
\hline 13 & Fhllo1 & Cantaloupe & Fuhai, China & Hu Baishi, Nanjing Agricultural University & + \\
\hline 14 & Fhl102 & Cantaloupe & Fuhai, China & Hu Baishi, Nanjing Agricultural University & + \\
\hline 15 & Fhll03 & Cantaloupe & Fuhai, China & Hu Baishi, Nanjing Agricultural University & + \\
\hline 16 & Anh01 & Pumpkin & Anhui, China & Hu Baishi, Nanjing Agricultural University & + \\
\hline 17 & Anh02 & Pumpkin & Anhui, China & Hu Baishi, Nanjing Agricultural University & + \\
\hline 18 & NXF03 & Muskmelon & Ningxia, China & Hu Baishi, Nanjing Agricultural University & + \\
\hline 19 & NXF04 & Muskmelon & Ningxia, China & Hu Baishi, Nanjing Agricultural University & + \\
\hline 20 & SD01 & Watermelon & Shandong, China & Hu Baishi, Nanjing Agricultural University & + \\
\hline 21 & SD02 & Watermelon & Shandong, China & Hu Baishi, Nanjing Agricultural University & + \\
\hline 22 & NM01 & Watermelon & Neimenggu, China & Hu Baishi, Nanjing Agricultural University & + \\
\hline 23 & NM02 & Watermelon & Neimenggu, China & Neimenggu Agricultural University & + \\
\hline 24 & HN01 & Watermelon & Hainan, China & Hu Baishi, Nanjing Agricultural University & + \\
\hline 25 & HNO2 & Watermelon & Hainan, China & Hu Baishi, Nanjing Agricultural University & + \\
\hline 26 & HB01 & Watermelon & Hebei, China & Hu Baishi, Nanjing Agricultural University & + \\
\hline 27 & HB02 & Watermelon & Hebei, China & Hu Baishi, Nanjing Agricultural University & + \\
\hline 28 & HB03 & Watermelon & Hebei, China & Hu Baishi, Nanjing Agricultural University & + \\
\hline 29 & NX01 & Watermelon & Ningxia, China & Hu Baishi, Nanjing Agricultural University & + \\
\hline 30 & NX02 & Watermelon & Ningxia, China & Hu Baishi, Nanjing Agricultural University & + \\
\hline 31 & NX03 & Watermelon & Ningxia, China & Hu Baishi, Nanjing Agricultural University & + \\
\hline 32 & NX04 & Watermelon & Ningxia, China & Hu Baishi, Nanjing Agricultural University & + \\
\hline 33 & YN01 & Watermelon & Yunnan, China & Hu Baishi, Nanjing Agricultural University & + \\
\hline 34 & YN02 & Watermelon & Yunnan, China & Hu Baishi, Nanjing Agricultural University & + \\
\hline 35 & SY-1 & Watermelon & Sanya, China & Henan Agricultural University & + \\
\hline 36 & $\mathrm{ZZ}-2$ & Watermelon & Zhengzhou, China & Henan Agricultural University & + \\
\hline 37 & JL01 & Watermelon & Jiln, China & Hu Baishi, Nanjing Agricultural University & + \\
\hline 38 & JL02 & Watermelon & Jiln, China & Hu Baishi, Nanjing Agricultural University & + \\
\hline 39 & Hunan01 & Watermelon & Hunan, China & Hu Baishi, Nanjing Agricultural University & + \\
\hline 40 & Hunan02 & Watermelon & Hunan, China & Hu Baishi, Nanjing Agricultural University & + \\
\hline 41 & Hunan03 & Watermelon & Hunan, China & Hu Baishi, Nanjing Agricultural University & + \\
\hline 42 & JS01 & Watermelon & Jiangsu, China & Hu Baishi, Nanjing Agricultural University & + \\
\hline 43 & ATCC29625 & Watermelon & Georgia, United States & R. Walcott, University of Georgia & + \\
\hline 44 & AACAU-9 & Cantaloupe & Australia & R. Walcott, University of Georgia & + \\
\hline 45 & $94-21$ & Watermelon & Georgia, United States & R. Walcott, University of Georgia & + \\
\hline 46 & FC440 & Cantaloupe & Xinjiang, China & N. W. Schaad, FDWSRU & + \\
\hline 47 & FC464 & Cantaloupe & Xinjiang, China & N. W. Schaad, FDWSRU & + \\
\hline 48 & $00-1$ & Watermelon & Georgia, United States & R. Walcott, University of Georgia & + \\
\hline 49 & $94-36$ & Watermelon & Georgia, United States & R. Walcott, University of Georgia & + \\
\hline 50 & $94-21$ & Watermelon & Georgia, United States & R. Walcott, University of Georgia & + \\
\hline 51 & $92-17$ & Watermelon & Indiana, United States & R. Walcott, University of Georgia & + \\
\hline 52 & $94-55$ & Watermelon & Georgia, United States & R. Walcott, University of Georgia & + \\
\hline 53 & $94-87$ & Watermelon & Florida, United States & R. Walcott, University of Georgia & + \\
\hline 54 & $94-39$ & Watermelon & Georgia, United States & R. Walcott, University of Georgia & + \\
\hline 55 & $94-48$ & Watermelon & Georgia, United States & R. Walcott, University of Georgia & + \\
\hline 56 & 201-12 & Watermelon & South Carolina, United States & R. Walcott, University of Georgia & + \\
\hline 57 & $94-12$ & Watermelon & Georgia, United States & R. Walcott, University of Georgia & + \\
\hline 58 & $203-50$ & Cantaloupe & Chile & R. Walcott, University of Georgia & + \\
\hline
\end{tabular}

(continued on next page)

\footnotetext{
a FDWSRU = Foreign Disease-Weed Science Research Unit.

${ }^{b}$ Padlock probe (PLP) results: $+=$ product of the expected size was produced and $-=$ no product was produced.
} 
(GenBank DQ.668361), containing greater than five mismatches to known sequences in the public domain.

Ligation and exonuclease treatment. $A$. citrulli genomic DNA was digested using EcoRI, HindIII, and BamHI (TaKaRa) for 30 min, and used as a template as described below. Cycled ligation was conducted in $10-\mu \mathrm{l}$ reactions containing $20 \mathrm{mM}$ Tris- $\mathrm{HCl}(\mathrm{pH}$ 9.0), $25 \mathrm{mM} \mathrm{KCH}{ }_{3} \mathrm{COO}, 10 \mathrm{mM} \mathrm{Mg}\left(\mathrm{CH}_{3} \mathrm{COO}\right)_{2}, 10 \mathrm{mM}$ dithiothreitol (DTT), $1 \mathrm{mM}$ nicotinamide adenine dinucleotide (NAD), $0.1 \%$ Triton X-100, $2.4 \mathrm{U}$ of Taq DNA ligase (New England Biolabs), and 50 pM PLP. Reaction mixtures were kept on ice and transferred rapidly into a thermal cycler. After $5 \mathrm{~min}$ at $95^{\circ} \mathrm{C}, 20$ cycles of $30 \mathrm{~s}$ at $95^{\circ} \mathrm{C}$ and $5 \mathrm{~min}$ at $65^{\circ} \mathrm{C}$ were performed, followed by $15 \mathrm{~min}$ at $95^{\circ} \mathrm{C}$ to inactivate the reaction. After ligation, $10 \mu \mathrm{l}$ of exonuclease mixture (10 mM Tris- $\mathrm{HCl}[\mathrm{pH} 9.0], 4.4 \mathrm{mM} \mathrm{MgCl}{ }_{2}$, bovine serum albumen at $0.1 \mathrm{mg} / \mathrm{ml}, 0.5 \mathrm{U}$ of Exonuclease I [TaKaRa], and $0.5 \mathrm{U}$ of Exonuclease III [TaKaRa]) were added to each reaction, and the samples were incubated at $37^{\circ} \mathrm{C}$ for $15 \mathrm{~min}$, followed by inactivation at $95^{\circ} \mathrm{C}$ for $3 \mathrm{~min}$.

To determine the specificity of the PLP assay, genomic DNA from 112 bacterial strains (Table 1) was extracted using the TIANamp Bacteria DNA Kit (TIANamp BIOTECH) following the manufacturer's instructions, resuspended in a 100- $\mu$ l Tris-EDTA

Table 1. (continued from preceding page)

\begin{tabular}{|c|c|c|c|c|c|}
\hline No. & Strains & Host & Origin & Reference or source $^{\mathrm{a}}$ & $\mathbf{P L P}^{\mathbf{b}}$ \\
\hline 59 & 206-102 & $\ldots$ & China & R. Walcott, University of Georgia & + \\
\hline 60 & 206-103 & $\ldots$ & China & R. Walcott, University of Georgia & + \\
\hline 61 & $208-27$ & Watermelon & Indiana, United States & R. Walcott, University of Georgia & + \\
\hline 62 & $205-14$ & Watermelon & Indiana, United States & R. Walcott, University of Georgia & + \\
\hline 63 & $92-301$ & $\ldots$ & Georgia, United States & R. Walcott, University of Georgia & + \\
\hline 64 & $92-305$ & $\ldots$ & Georgia, United States & R. Walcott, University of Georgia & + \\
\hline 65 & $92-300$ & $\ldots$ & Georgia, United States & R. Walcott, University of Georgia & + \\
\hline 66 & $201-18$ & Watermelon & Australia & R. Walcott, University of Georgia & + \\
\hline 67 & $98-17$ & Pumpkin & Georgia, United States & R. Walcott, University of Georgia & + \\
\hline 68 & $99-5$ & Cantaloupe & Georgia, United States & R. Walcott, University of Georgia & + \\
\hline 69 & $200-23$ & Watermelon & Oklahoma, United States & R. Walcott, University of Georgia & + \\
\hline 70 & $200-6$ & Watermelon & Georgia, United States & R. Walcott, University of Georgia & + \\
\hline 71 & $202-66$ & Cantaloupe & Israel & R. Walcott, University of Georgia & + \\
\hline 72 & $203-55$ & Watermelon & Honduras & R. Walcott, University of Georgia & + \\
\hline 73 & $207-41$ & $\ldots$ & China & R. Walcott, University of Georgia & + \\
\hline 74 & 206-1 & $\ldots$ & China & R. Walcott, University of Georgia & + \\
\hline 75 & 206-2 & $\ldots$ & China & R. Walcott, University of Georgia & + \\
\hline 76 & A. avenae $\mathrm{FC} 371$ & Corn & United States & N. W. Schaad, FDWSRU & - \\
\hline 77 & A. avenae $\mathrm{FC} 358$ & Corn & United States & N. W. Schaad, FDWSRU & - \\
\hline 78 & A. avenae ATCC 19307 & Sugarcane & Reunion & China Academy of Inspection and Quarantine & - \\
\hline 79 & A. cattleyae NCPPB4196 & $\ldots$ & $\ldots$ & China Academy of Inspection and Quarantine & - \\
\hline 80 & A. cattleyae NCPPB4198 & & & China Academy of Inspection and Quarantine & - \\
\hline 81 & A. cattleyae ATCC 10200 & Cattleya sp. & California, United States & R. Walcott, University of Georgia & - \\
\hline 82 & A. facilis A.f-019 & & United States & The United States of America STA & - \\
\hline 83 & A. facilis A.f- 9503 & & United States & R. Walcott, University of Georgia & - \\
\hline 84 & A. konjaci АTCC 33996 & Konjac & Japan & R. Walcott, University of Georgia & - \\
\hline \multirow[t]{2}{*}{85} & \multirow{2}{*}{$\begin{array}{l}\text { Xanthomonas oryzae pv. oryzae } \\
\text { YN24 }\end{array}$} & & & & - \\
\hline & & Rice & Yunnan, China & Hu Baishi, Nanjing Agricultural University & \\
\hline 86 & Х. oryzae pv. oryzae Pxo99 & Rice & Philippines & China Academy of Inspection and Quarantine & - \\
\hline 87 & X. oryzae pv. oryzicola JSb3-21 & Rice & Jiangsu, China & Hu Baishi, Nanjing Agricultural University & - \\
\hline 88 & X. campestris pv. campestris Xcc & Cabbage & Nanjing, China & Hu Baishi, Nanjing Agricultural University & - \\
\hline 89 & Erwinia amylovora NCPPB 1665 & Pear & United States & China Academy of Inspection and Quarantine & - \\
\hline 90 & E. amylovora IL6 & Rubus sp. & Illinois, United States & China Academy of Inspection and Quarantine & - \\
\hline 91 & E. pyrifoliae $\mathrm{EP} 28 / 96$ & Pear & Korea & China Academy of Inspection and Quarantine & - \\
\hline 92 & E. pyrifoliae DSMZ12163 & Pear & Korea & China Academy of Inspection and Quarantine & - \\
\hline 93 & E. pyrifoliae $\mathrm{EjP}$ & Pear & Japan & China Academy of Inspection and Quarantine & - \\
\hline 94 & E. tasmaniensis DSMZ17950 & Apple & Tasmania, Australia & China Academy of Inspection and Quarantine & - \\
\hline 95 & E.billingiaeDSMZ17872 & & & China Academy of Inspection and Quarantine & - \\
\hline 96 & E. psidii NCPPB3555 & & Brazil & China Academy of Inspection and Quarantine & - \\
\hline \multirow[t]{2}{*}{97} & \multirow{2}{*}{$\begin{array}{l}\text { Pectobacterium carotovorum subsp. } \\
\text { carotovorum ATCC } 138\end{array}$} & & & & - \\
\hline & & Potato & Arizona, United States & China Academy of Inspection and Quarantine & \\
\hline 98 & Gibbsiella quercinecans & Pear & Jiangsu, China & Hu Baishi, Nanjing Agricultural University & - \\
\hline 99 & Dickeya chrysanthemi NCPPB2309 & Chrysanthemum & Italy & China Academy of Inspection and Quarantine & - \\
\hline \multirow[t]{2}{*}{100} & \multirow{2}{*}{$\begin{array}{l}\text { Pantoea stewartii subsp. stewartii } \\
\text { ATCC } 8199\end{array}$} & & & & - \\
\hline & & Corn & Rugosa, United States & China Academy of Inspection and Quarantine & \\
\hline \multirow[t]{2}{*}{101} & \multirow{2}{*}{$\begin{array}{l}\text { P. stewartii subsp. stewartii } \\
\text { ATCC } 8200\end{array}$} & & & & - \\
\hline & & Corn & Rugosa, United States & China Academy of Inspection and Quarantine & \\
\hline \multirow[t]{2}{*}{102} & \multirow{2}{*}{$\begin{array}{l}\text { P. agglomerans pv. gypsophilae } \\
\text { DCSS6 }\end{array}$} & & & & - \\
\hline & & Gypsophila & $\ldots$ & South China Agricultural University & \\
\hline 103 & P. stewartii subsp. indologenes & & & & - \\
\hline \multirow{3}{*}{104} & DCSS1 & $\ldots$ & $\ldots$ & South China Agricultural University & \\
\hline & \multirow{2}{*}{$\begin{array}{l}\text { Pseudomonas syringae pv. tomato } \\
\text { DC } 3000\end{array}$} & & & & - \\
\hline & & Tomato & Guernsey, United Kingdom & China Academy of Inspection and Quarantine & \\
\hline 105 & P. syringae pv. lachrymans Ps18 & Cucumber & & China Academy of Agricultural Sciences & - \\
\hline 106 & P. fluorescens $\mathrm{Pf}$ & $\ldots$ & Nanjing, China & Hu Baishi, Nanjing Agricultural University & - \\
\hline 107 & P. putida $\mathrm{Pp}$ & $\ldots$ & Nanjing, China & Hu Baishi, Nanjing Agricultural University & - \\
\hline 108 & P. syringae pv. tabaci ATCC 11527 & $\ldots$ & $\ldots$ & China Academy of Inspection and Quarantine & - \\
\hline 109 & P. syringae pv. atropur $\mathrm{NCPPB} 1328$ & $\ldots$ & $\ldots$ & China Academy of Inspection and Quarantine & - \\
\hline 110 & Ralstonia solanacearum & $\ldots$ & Nanjing, China & Hu Baishi, Nanjing Agricultural University & - \\
\hline 111 & Bacillus cereus $\mathrm{Bc}$ & $\ldots$ & Nanjing, China & Hu Baishi, Nanjing Agricultural University & - \\
\hline 112 & Escherichia coli Eco & $\ldots$ & $\ldots$ & China Academy of Sciences & - \\
\hline
\end{tabular}


(TE) buffer, and subjected to cycled ligation as described above, then PCR amplification. To determine the amplification efficiency of the PLP assay, 10-fold serial dilutions of pure A. citrulli genomic DNA were generated at $10 \mathrm{ng} / \mu \mathrm{l}$ to $100 \mathrm{fg} / \mu \mathrm{l}$ and tested by the PLP assay.

PCR amplification. Amplification of the PLP was carried out in an ABI 2720 thermal cycler (Applied Biosystems) in 25- $\mu$ l reactions containing $3 \mathrm{mM} \mathrm{MgCl} 2,200 \mathrm{nM}$ dNTP, $300 \mathrm{nM}$ primers $\mathrm{P}_{1^{-}}$ F (5'-CCGAGATGTACCGCTATCGT- $\left.3^{\prime}\right)$ and $\mathrm{P}_{2}$-R (5'-TCATGC TGCTAACGGTCGAG-3'), 1 U of Taq HotStart polymerase (TaKaRa), 0.6 U of uracil DNA glycosylase (New England Biolabs), and $3 \mu \mathrm{l}$ of ligation-exo mixture as template. The reaction mixture was initially incubated at $50^{\circ} \mathrm{C}$ for $2 \mathrm{~min}$, followed by 10 min of denaturation at $95^{\circ} \mathrm{C}$ and 40 cycles of $15 \mathrm{~s}$ at $95^{\circ} \mathrm{C}$ and 1 min at $60^{\circ} \mathrm{C}$. The reaction was then immediately cooled to $10^{\circ} \mathrm{C}$ and PLP amplicons were analyzed by $2.5 \%$ agarose gel electrophoresis at $120 \mathrm{~V}$ for $30 \mathrm{~min}$.

Dot-blot hybridization. Dot-blot hybridization was conducted as described by Saiki (18). Briefly, $1 \mu \mathrm{l}$ of PLP amplicons was spotted onto a specific position on the membrane $\left(\right.$ Hybond $-\mathrm{N}^{+}$; Amersham). Ultraviolet cross-linking of DNA to the membrane was carried out for $30 \mathrm{~s}$ on a UV hybrilinker (UVP HL-2000); then, the membrane was rinsed briefly in $2 \times \mathrm{SSC}(1 \times \mathrm{SSC}$ is 0.15 $\mathrm{M} \mathrm{NaCl}$ plus $0.015 \mathrm{M}$ sodium citrate) containing $1 \%$ sodium dodecyl sulfate (SDS) for $2 \mathrm{~min}$ at room temperature. The membrane was subsequently air dried for approximately $10 \mathrm{~min}$ at room temperature. cZipcode oligonucleotides (5'-ACTCTCGACCTAGCG TAAGG-3') were digoxigenin-labeled and hybridization was carried out for $4 \mathrm{~h}$ at $42^{\circ} \mathrm{C}$. Membranes were washed twice in $2 \times \mathrm{SSC}$ and $0.1 \% \times$ SDS for $5 \mathrm{~min}$ at room temperature, twice in $0.5 \% \times$ SSC and $0.1 \% \times$ SDS for $15 \mathrm{~min}$ at $68^{\circ} \mathrm{C}$, and once in maleic acid buffer for $2 \mathrm{~min}$ at room temperature. To detect hybridization, the membrane was incubated with anti-digoxigenin antibody conjugated with alkaline phosphatase diluted $1: 250$ in $0.1 \mathrm{M}$ Tris- $\mathrm{HCl}$ and $0.15 \mathrm{M} \mathrm{NaCl}$ with $1 \%$ blocking reagent (Roche Applied Science). After washing the membrane three times in detection buffer (0.1 M Tris- $\mathrm{HCl}$ and $0.1 \mathrm{M} \mathrm{NaCl}, \mathrm{pH} 9.5)$, a substrate consisting of nitroblue tetrazolium-bromo-chloro-indolyl phosphate (NBTBCIP) (Roche Applied Science) was layered over the membrane. The chromogenic reaction was allowed to proceed for 2 to $8 \mathrm{~h}$ in the dark and stopped by dipping membranes in TE buffer $(1 \mathrm{mM}$ EDTA and $1 \mathrm{mM}$ TrisCl, $\mathrm{pH}$ 8.0) for approximately $5 \mathrm{~min}$.

PLP assay detection of $A$. citrulli in artificially infested seed. Cantaloupe seed ( $40 \mathrm{~g}$ ) were artificially inoculated by incubation for $20 \mathrm{~min}$ in a $200-\mathrm{ml}$ cell suspension containing A. citrulli at approximately $1 \times 10^{8} \mathrm{CFU} / \mathrm{ml}$ of phosphate-buffered saline (PBS). Seed were then air dried and mixed with noninfested seed to generate seedlots with $0 \%(0 / 1,000$ seeds), $0.1 \%$ (1/1,000 seeds) $10 \%$ (10/1,000 seeds), $5 \%$ (50/1,000 seeds), and 10\% (100/1,000 seeds) infestation. Seedlots were incubated with $200 \mathrm{ml}$ of PBS with Tween (PBST) for $4 \mathrm{~h}$ on an incubator shaker (Zhicheng). Seed were processed for pathogen extraction as described by
Walcott et al. (27). Briefly, seed samples ( $n=1,000$ seeds/lot) were incubated in $50 \mathrm{ml}$ of PBST for $4 \mathrm{~h}$ on a shaker (Zhicheng). The seed suspension was passed through a triple layer of cheesecloth to remove the seeds and $50 \mathrm{ml}$ of seed wash was pelleted by centrifugation at $6,000 \times g$ for $3 \mathrm{~min}$. The pellet was resuspended in $5 \mathrm{ml}$ of PBST and filtered through number 1 filter paper (Whatman). Seed wash $(2 \mu \mathrm{l})$ was used as template for the PLP assay combined with dot-blot hybridization as described above. For comparison, conventional PCR was conducted directly on $2 \mu \mathrm{l}$ of seed wash using primers WFB1 and WFB2 (27). This experiment was repeated three times.

Evaluation of PLP assay for detection of $\boldsymbol{A}$. citrulli in naturally infested seed. To evaluate the ability of the PLP assay to detect $A$. citrulli in naturally infested seed, melon seed samples from markets in Xinjiang province (Xinmiza-1, Xinmi-11, Xinmi1, Xinmi-32, Xinmiza-7, Xinmi-18, Xinmi-25, and Xinmi-36) and watermelon seed collected from Ningxia province (R001-R047) were tested by PLP assay combined with dot-blot hybridization as described above and conventional PCR using primers WFB1 and WFB2. Seed samples ( $n=1,000$ seeds) from each lot and the negative control from the $A$. citrulli-free seed wash were processed as described above, and this experiment was repeated three times.

To confirm the results, $100 \mu \mathrm{l}$ of seed wash from positive seedlots was plated on semiselective media TWZ $(0.5 \%$ peptone,

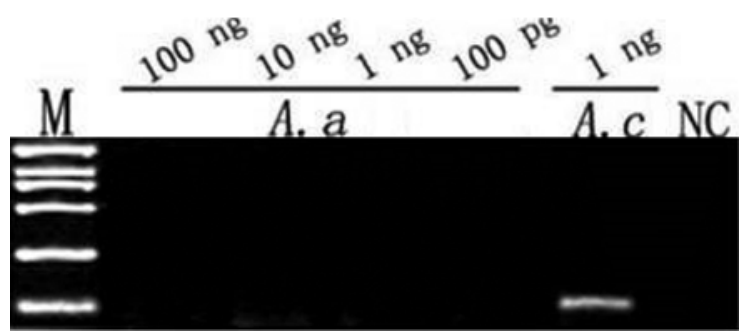

Fig. 2. Specificity of the Acidovorax citrulli padlock probe (PLP) using genomic DNA of $A$. citrulli and $A$. avenae. Ligation of PLP P-ac on genomic DNA of $A$. avenae does not result in a positive signal even in the presence of a very high amount of DNA. Template DNAs are indicated on the top. NC, negative control; M, DL2000 maker (TaKaRa)

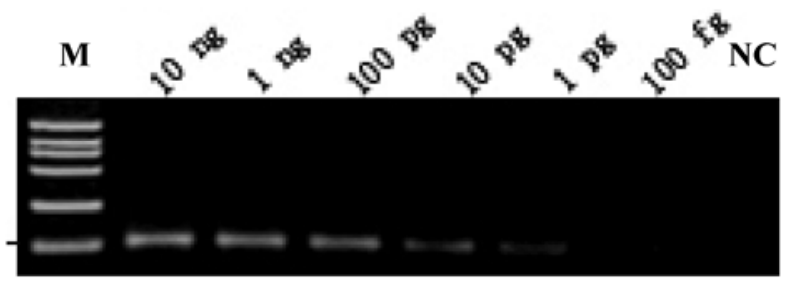

Fig. 3. Detection of 10 -fold serial dilutions of Acidovorax citrulli DNA with the padlock probe assay using agarose gel electrophoresis. NC, negative control; M, DL2000 marker (TaKaRa).
A.citrulli JQ743876
A.citrulli GU339092
A.citrulli GU339093
A.citrulli DQ360418
A.a.avenae JQ743887
A. a.avenae EU368726
A. a. avenae JQ743875
A.a.avenae AY080997
A.facilis DQ360425
A.konjaci GU339095
A.cattleyae AY572032
A.cattleyae GU339094

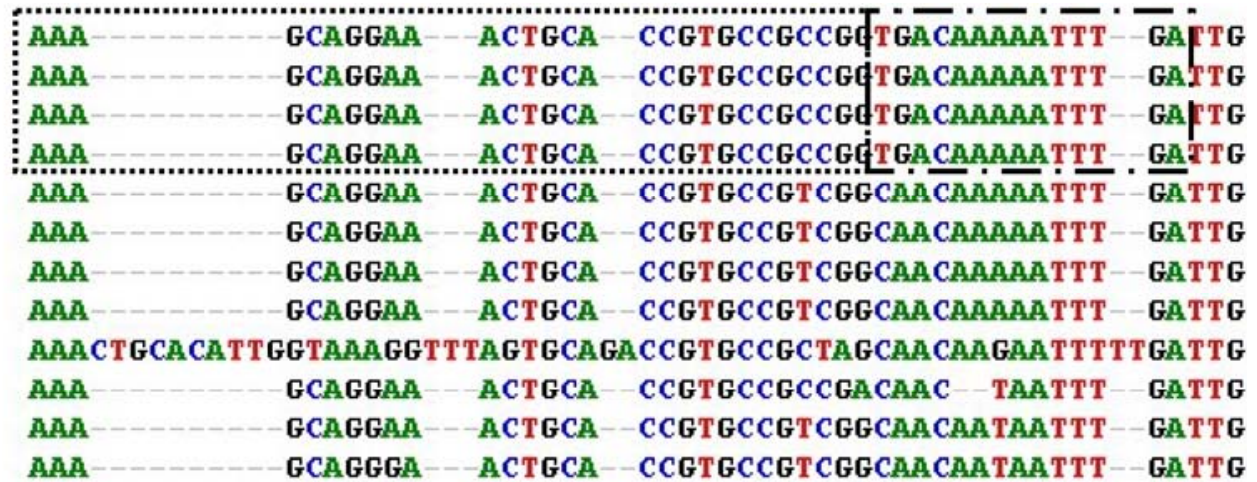

Fig. 1. Part of a multiple alignment of $16 \mathrm{~S}-23 \mathrm{~S}$ internal transcribed spacer sequences of Acidovorax citrulli and related bacteria. Symbols: ...... $=$ the target sequence of $\mathrm{T} 1$ and.$--=$ the target sequence of $\mathrm{T} 2$. 
$0.025 \% \mathrm{CaCl}_{2}, 1 \%$ Tween- 80 , berberine at $50 \mathrm{mg} / \mathrm{liter}$, cycloheximide at $50 \mathrm{mg} / \mathrm{liter}$, and 2,3,5-triphenyltetrazolium chloride at $50 \mathrm{mg} /$ liter). After incubation for $24 \mathrm{~h}$ at $28^{\circ} \mathrm{C}$, putative red $A$. citrulli colonies were selected for verification by PCR with universal 16S rDNA primers fd2/rp1 (30), and amplicons were sequenced (TaKaRa Company). To confirm the identity of putative A. citrulli strains from positive seedlots, database searches were performed with the BLASTn algorithm (1).

\section{Results}

Testing of the diagnostic PLP. The PLP assay detected all $A$. citrulli strains tested and did not cross-react with nontarget bacteria, including closely related Acidovorax spp. (Table 1). In particular, ligation of the PLP P-Ac did not occur with high concentra-

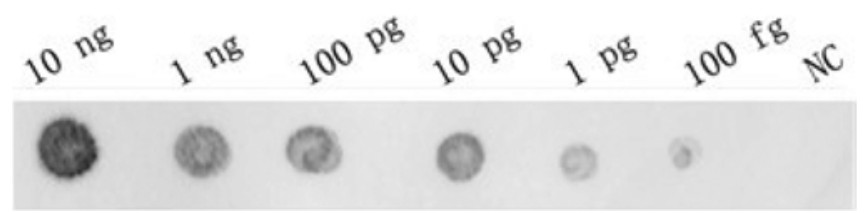

Fig. 4. Detection of 10 -fold serial dilutions of Acidovorax citrulli DNA with the padlock probe assay using dot- blot hybridization. NC, negative control.

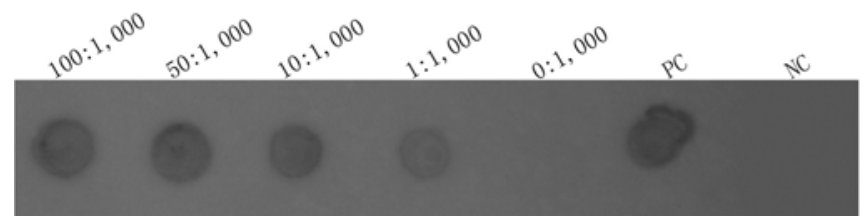

Fig. 5. Detection of Acidovorax citrulli in cantaloupe seedlots with different levels of artificial infestation ranging from $10 \%$ (spot 1) to $0 \%$ (spot 5) using a padlock probe assay combined with dot-blot hybridization. PC, and. NC, negative control. tions of $A$. avenae (100 ng) genomic DNA (Fig. 2). Because $A$. avenae is closely related to $A$. citrulli, these data indicated that the PLP is highly specific.

Sensitivity of PLP assay. The PLP assay detected the target DNA in solutions containing $1 \mathrm{pg}$ of genomic DNA by agarose gel electrophoresis (Fig. 3), and $100 \mathrm{fg}$ of genomic DNA by dot-blot hybridization (Fig. 4). In each of three attempts, the A. citrulli genomic DNA was detected at $10 \mathrm{ng}, 1 \mathrm{ng}, 100 \mathrm{pg}, 10 \mathrm{pg}$, and $1 \mathrm{pg}$ of genomic DNA by agarose gel electrophoresis and dot-blot hybridization. Three attempts using agarose gel electrophoresis failed to detect $A$. citrulli genomic DNA at $100 \mathrm{fg}$ of genomic DNA. In contrast, in all three attempts, the $A$. citrulli genomic DNA was detected at $100 \mathrm{fg}$ of genomic DNA by dot-blot hybridization.

Detection of $A$. citrulli in cucurbit seed. Conventional PCR failed to detect $A$. citrulli in artificially infested cantaloupe seed with varying levels of $A$. citrulli inoculum. In contrast, the PLP assay detected A. citrulli in $100 \%$ of the seedlots with 10, 5, 1, and $0.1 \%$ infestation (Fig. 5).

Using naturally infested seedlots, the PLP assay detected A. citrulli in 4 of 8 cantaloupe seedlots from Xinjiang markets and 15 of 47 watermelon seedlots from Ningxia (Fig. 6). To confirm the results, seed wash from the PLP-positive lots was plated on semiselective media TWZ. All of the PLP-positive seed wash yielded $A$. citrulli colonies. In contrast, conventional PCR using WFB1 and WFB2 primers detected $A$. citrulli in 1 of 8 cantaloupe seedlots and 5 of 47 watermelon seedlots.

\section{Discussion}

The standard seed health assays for A. citrulli, the seedling grow-out assay, and isolation of the pathogen from the seed are time-consuming and inefficient. Immunological assays have also been used but their effectiveness is strongly influenced by the quality of the antibody employed. Additionally, immunological assays are generally less sensitive than PCR-based assays. Microarrays or macroarrays, multiplex detection methods that use universal pri-

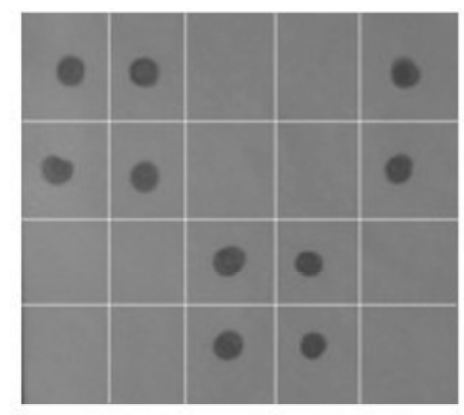

A

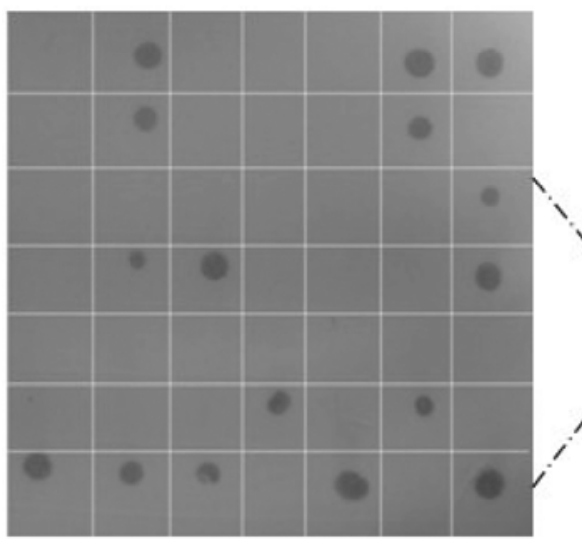

C

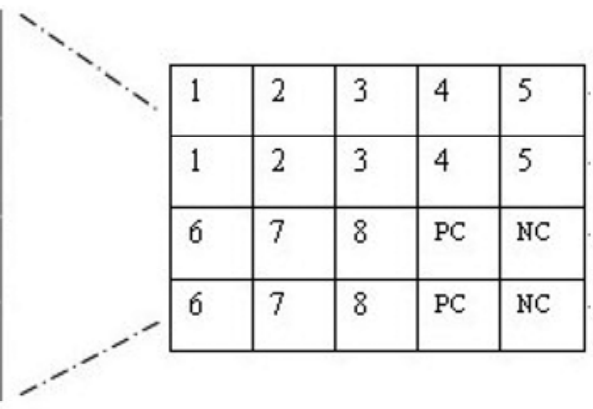

B

Fig. 6. Detection of Acidovorax citrulli in A, cantaloupe and $\mathbf{C}$, watermelon seed samples using a padlock probe assay combined with dot-blot hybridization. B and $\mathbf{D}$, Layout of targets from each sample on membrane. B, Analyzed samples were 1, Xinmiza-1; 2, Xinmi-11; 3, Xinmi-1; 4, Xinmi-32; 5, Xinmiza-7; 6, Xinmi-18; 7, Xinmi-25; and 8, Xinmi-36. D, Identifiers R001 to R047 represent watermelon seedlots from Ningxia. PC, positive control and NC, negative control. 
mers to detect variable regions of PLPs, facilitate high-throughput diagnostics $(8,12,25,26)$. Because of their high sensitivity and specificity, PLPs have been used to detect single-nucleotide variations in DNA $(2,3,7)$. The homology of the 16S-23S rDNA ITS sequences between A. citrulli and A. avenae can be as high as $98 \%$. Hence, it is difficult to differentiate these species based on this locus. For instance, one ITS-based PCR primer set designed for $A$. citrulli, SEQID (20), did not perform well at high-stringency conditions, making assays with this primer set more prone to falsepositive results. In this study, we designed and tested a PLP for $A$. citrulli. The PLP was designed based on the 16S-23S ITS rDNA sequence from $A$. citrulli. In all, 75 A. citrulli strains from six different countries around the world were detected by the PLP assay and the assay did not cross-react with nontarget bacteria, including closely related Acidovorax spp.

The assay facilitated detection of the pathogen in naturally infested watermelon and cantaloupe seed. The seedlots that were positive for $A$. citrulli were confirmed by isolation of the pathogen on semiselective media. The PLP assay detected A. citrulli in 4 of 8 cantaloupe seedlots from Xinjiang markets and 15 of 47 watermelon seedlots from Ningxia, and the detection of naturally infested seedlots was consistent. In contrast, conventional PCR using WFB 1 and WFB2 primers detected A. citrulli in 1 of 8 cantaloupe seedlots and 5 of 47 watermelon seedlots. All three replications of the PLP assay on the naturally infested seed lots resulted in positive detections of $A$. citrulli. Plating the seed washes for detection of $A$. citrulli on agar media took considerable time and was subject to false-positive results. Confirmed by isolation of the pathogen on semiselective media, the results of PLP assay were validated, indicating that the PLP assay provides reliable and sensitive diagnosis.

Including sample processing, the PLP assay required approximately 13 to $19 \mathrm{~h}$ to test seedlots ( $n=1,000$ seeds/sample). As described by Lunebery et al. (13), dot-blot hybridization was 10 times more sensitive than agarose gel electrophoresis with ethidium bromide staining for detection of $A$. citrulli. Compared with traditional $A$. citrulli seed health assays such as seedling grow-out, the PLP-based assay requires significantly less time. Although dotblot hybridization increases completion time, it also increases detection sensitivity, which should yield more accurate results.

\section{Acknowledgments}

Y. Tian and Y. Zhao contributed equally to this research. This research was supported by the China High Technology Research and Development Project (number 2012AA101501), National Basic Research Program of China (number2009CB119200), Science and Technology support XinJiang project (number 201191133), and the Research and Development Special Fund for Public Welfare Industry (number 201003066).

\section{Literature Cited}

1. Altschul, S. F., Madden, T. L., Schaffer, A. A., Zhang, J., Zhang, Z., Miller, W., and Lipman, D. J. 1997. Gapped BLAST and PSI-BLAST: A new generation of protein database search programs. Nucleic Acids Res. 25:3389-3402.

2. Antson, D. O., Isaksson, A., Landegren, U., and Nilsson, M. 2000. PCRgenerated padlock probes detect single nucleotide variation in genomic DNA. Nucleic Acids Res. 28:e58.

3. Antson, D. O., Maritha, M. H., Landegren, U., and Nilsson, M. 2003.PCRgenerated padlock probes distinguish homologous chromosomes through quantitative fluorescence analysis. Eur. J. Human Genet. 11:357-363.

4. Boer, S. H., Ward, L. J., Li, X., and Chlttaranjan, S. 1995. Attenuation of PCR inhibition in the presence of plant compounds by addition of blotto. Nucleic Acids Res. 23:2567-2568.

5. Burdman, S., and Walcott, R. 2012. Acidovorax citrulli: generating basic and applied knowledge to tackle a global threat to the cucurbit industry. Mol. Plant Pathol. 13:805-815.

6. Cai, X. Q., Huang, Y. Y., Yang, J. Z., Chen, J., Cai, G. L., and Hu, F. P. 2005. Pathogen identification of bacterial fruit blotch of watermelon in Fujian. J. Fujian Agric. For. Univ. 34:434-437.

7. Edwards, K. J., Reid, A. L., Coghill, J. A., Berry, S. T., and Barker, G. L.2009. Multiplex single nucleotide polymorphism (SNP)-based genotyping in allohexaploid wheat using padlock probes. Plant Biotechnol. J. 7:375-390.

8. Fessehaie, A., Solke, H., Boer, D., and Levesque, A. C. 2003. An oligonucleotide array for the identification and differentiation of bacteria pathogenic on potato. Phytopathology 93:262-269.

9. Hu. J., Huang, J. X., Liu, S. P., Wang, L. J., and Yang, L. G. 2006. Identification of the bacterial blotch of watermelon in Jiuquan district of Nei
Menggu Province. China Plant Prot. 26:19-20.

10. Jin, Y., Zhang, J. J., Wu, Y. H., and Gao, J. 2004. Occurrence of watermelon bacterial fruit blotch and identification of its pathogens. J. Jilin Agric. Univ. 26:263-266.

11. Kaocharoen, S., Wang, B., Tsui, K. M., Trilles, L., Kong, F., and Meyer, W. 2008. Hyperbranched rolling circle amplification as a rapid and sensitive method for species identification within the Cryptococcus species complex. Electrophoresis 29:3183-3191.

12. Levesque, C. A., Harlton, C. E., and Arthur, W. A. M. 1998. Identification of some oomycetes by reverse dot blot hybridization. Phytopathology $88: 213-222$.

13. Lunebeng, E., Jensen, J. S., and Forsch, M. 1993. Detection of Mycoplasma pneumoniae by polymerase chain reaction and nonradioactive hybridization in micro titer plates. J. Clin. Microbiol. 31:1088-1094.

14. Minsavage, G. V., Hoover, R. J., Kucharek, T. A., and Stall, R. E. 1995. Detection of the watermelon fruit blotch pathogen on seeds with the polymerase chain reaction. (Abstr.) Phytopathology 85:1162.

15. Nilsson, M., Malmgren, H., Samiotaki, M., Kwiatkowski, M., Chowdhary, B.P., and Landegren, U. 1994. Padlock probes: circularizing oligonucleotides for localized DNA detection. Science 265:2085-2088.

16. Rane, K. K., and Latin, R. X. 1992. Bacterial fruit blotch of watermelon: association of the pathogen with seed. Plant Dis. 76:509-512.

17. Ren, X. P., Li, X. N., Wang, L., Sun, J. X., Wu, J. L. and Liu, Q. G. 2010. Identification for pathogen of bacterial fruit blotch of watermelon in Guangdong province. J. South China Agric. Univ. 31:40-43.

18. Saiki, R. K., Walsh, P. S., Levenson, C. H., and Erlich, H. A. 1989. Genetic analysis of amplified DNA with immobilized sequence-specific oligonucleotide probes. Proc. Natl. Acad. Sci. USA 86:6230-6234.

19. Schaad, N. W., Postnikova, E., Sechler, A., Claflin, L. E., Vidaver, A. K., Jones, J. B., Agarkova, I., Ignatov, A., Dickstein, E., and Ramundo, B. A. 2008. Reclassification of subspecies of Acidovorax avenae as A. avenae (Manns 1905) emend, A. cattleyae (Pavarino, 1911) comb. nov., A. citrulli (Schaad et al., 1978) comb. nov., and proposal of A. oryzae sp. nov. Syst. Appl. Microbiol. 31:434-446.

20. Schaad, N. W., Song, W. Y., and Hatziloukas, E. 2000. PCR primers for detection of plant pathogenic species and subspecies of Acidovorax. US Patent no. 6146834. United States Patent and Trademark Office, Alexandria, VA.

21. Steain, M. C., Dwyer, D. E., Hurt, A. C., Kol, C., Saksena, N., Cunningham, A. L., and Wang, B. 2009. Detection of infiuenza $\mathrm{A}_{1} \mathrm{~N}_{1}$ and $\mathrm{H}_{2} \mathrm{~N}_{2}$ mutation conferring resistance to oseltamivir using rolling circle amplification. Antiviral Res. 84:242-248.

22. Szemes, M., Bonant, P., Weerdt, M. D., Baner, J., Landegren, U., and Schoen, C. D. 2005. Diagnostic application of padlock probes-multiplex detection of plant pathogens using universal microarrays. Nucleic Acids Res. 33:e70.

23. Tong, Z., Kong, F., Wang, B., Zeng, X., and Gilbert, G. L. 2007. A practica method for subtyping of Streptococcus agalactiae serotype III, of human origin, using rolling circle amplification. J. Microbiol. Methods 70:39-44.

24. Tsui, C. K., Wang, B., Khadempour, L., Alamouti, S. M., Bohlmann, J., Murray, B. W., and Hamelin, R. C. 2010. Rapid identification and detection of pine pathogenic fungi associated with mountain pine beetles by padlock probes. J. Microbiol. Methods 83:26-33.

25. Uehara, T., Kushida, A., and Momota, Y. 1999. Rapid and sensitive identification of Pratylenchus spp. using reverse dot blot hybridization. Nematology 1:549-555.

26. Van Doorn, R., Slawiak, M., Szemes, M., Dullemans, A. M., Bonants, P., Kowalchuk, G. A., and Schoen, C. D. 2009. Robust detection and identification of multiple oomycetes and fungi in environmental samples by using a novel cleavable padlock probe-based ligation detection assay. Appl Environ. Microbiol. 75:4185-4193.

27. Walcott, R. R, and Gitaitis, R. D. 2000. Detection of Acidovorax avenae subsp. citrulli in watermelon seed using immunomagnetic separations and the polymerase chain reaction. Plant Dis. 84:470-474.

28. Wang, B., Potter, S. J., Lin, Y., Cunningham, A. L., Dwyer, D. E., Su, Y., Ma, X., Hou, Y., and Saksena, N. K. 2005. Rapid and sensitive detection of severe acute respiratory syndrome coronavirus by rolling circle amplification. J. Clin. Microbiol. 43:2339-2444

29. Webb, R. E., and Goth, R. W. 1965. A seedborne bacterium isolated from watermelon. Plant Dis. 49:818-821.

30. Weisburg, W. G., Barns, S. M., Pelletier, D. A., and Lane, D. J. 1991.16S ribosomal DNA amplification for phylogenetic study. J. Bacteriol. 173:697-703.

31. Willems, A., Goor, M., Thielemans, S., Gilis, M., Kersters, K., and De Ley, J. 1992. Transfer of several phytopathogenic Pseudomonas species to Acidovorax as Acidovorax avenae subsp. avenae subsp. nov., comb. nov., Acidovorax avenae subsp. citruli, Acidovorax avenae subsp. cattleyae, and Acidovorax konjaci. Int. J. Syst. Bacteriol. 42:107-119.

32. Xue, L., Yang, C. D., Chen, X. R., Jia, Y. C., and Luo, D. L. 2009. Identification of the bacterial blotch of watermelon in Jiuquan district of Gansu province. China. Plant Prot. 35:53-57.

33. Zhang, X. L., and Mo, G. H. 1996. Occurrence of watermelon bacterial fruit blotch and identification of its pathogens in Xin Jiang. Xinjiang Agric. Sci. 4:183-184

34. Zhao, T. C., Zhao, H. H., and Wang, H. S. 2009. Occurrence of watermelon bacterial fruit blotch and identification of its pathogens in Shandong. Plant Prot. 35:170-171. 